\title{
Caracterización mecánica de morteros de cemento Portland con breas de petróleo y de alquitrán de carbón
}

\section{Mechanical characterization of Portland cement mortars containing petroleum or coal tar}

\author{
J. S. Alcaide ${ }^{(*)}$, E. G. Alcocel(*), E. Vilaplana(*), D. Cazorla(*) y $\underline{\text { P. Garcés }}{ }^{(*)}$
}

Recepción/Received: 26-I-07

Aceptación/Accepted: 4-IV-07

RESUMEN

En este artículo se presentan datos experimentales de resistencia a flexión y a compresión de morteros de cemento Portland con adición y sustitución de breas de petróleo y de alquitrán de carbón, que son subproductos de la industria del carbón o del petróleo. Los materiales estudiados son breas de alquitrán de carbón $\mathrm{A}$ (BACA) y $B$ (BACB), y dos breas de petróleo (BPP) y (BPT). Los datos demuestran la viabilidad del uso de estas breas en la fabricación de morteros con menores contenidos de cemento, permitiendo diseñar un nuevo material sostenible con el medio ambiente y que contribuya a reducir el impacto ambiental de los materiales de construcción, hecho que permite abrir una nueva vía de valorización de estos subproductos.

Palabras clave: cemento con adiciones, mortero, propiedades mecánicas, caracterización, sustitución.
SUMMARY

This article discusses experimental data on the flexural and compressive strength of Portland cement mortars containing additions or cement replacements consisting in petroleum or coal tar, by-products of the oil and coal industries. The materials studied were two coal (BACA and $B A C B$ ) and two petroleum (BPP and BPT) tars. The results show that it is feasible to use such materials as a partial replacement for cement in mortar manufacture. This should lead to the design of a new sustainable product that will contribute to lowering the environmental impact of construction materials while at the same time opening up an avenue for the re-use of this type of industrial by-products.

Keywords: blended cements, mortar, mechanical properties, characterization, substitution.

\section{INTRODUCCIÓN}

Las breas, como subproducto de la industria de carbón o petróleo, tienen entre otras aplicaciones como aglomerante en la fabricación de ánodos de carbón, la fabricación de coque o como precursoras de fibras de carbón (1-3).

\section{INTRODUCTION}

Tar, a by-product of the coal and oil industries, can be used to make coal anodes or coke or as carbon fibre precursors, among others (1-3).

(*) Universidad de Alicante (Alicante, España). 
La brea natural es un subproducto de elevado peso molecular resultante de la destilación del petróleo o del alquitrán de carbón. Las breas de petróleo y de alquitrán de carbón están constituidas por una compleja mezcla de hidrocarburos, fundamentalmente aromáticos y heterociclos (4). La elevada aromaticidad que presentan hace que reaccionen rápidamente para formar coque. Las breas naturales están compuestas por cuatro grupos de compuestos químicos: saturados, naftalenos, aromáticos polares y asfaltenos (5).

Estos materiales no habían sido nunca usados como adición para refuerzo de morteros de cemento Portland, contrariamente a las fibras de carbón, que han sido ampliamente estudiadas por las posibilidades que le aportan al hormigón (6-7). En un trabajo previo se ha realizado un estudio comparativo entre morteros fabricados con fibras de carbón y brea de petróleo de alto punto de reblandecimiento (8). Vistos los novedosos e interesantes resultados obtenidos con la brea se consideró oportuno caracterizar el comportamiento mecánico de morteros fabricados con sustitución y adición de otros tipos de brea de naturaleza y propiedades distintas. Estas breas, objeto de este estudio, son materiales que pueden ser calificados como subproductos de la industria del carbón o del petróleo.

Teniendo en cuenta su bajo coste en comparación con las fibras de carbón, se consideró interesante analizar el uso de diferentes tipos de brea como refuerzo de morteros a pesar de sus peores, a priori, propiedades mecánicas.

El objeto de este trabajo es caracterizar, a nivel mecánico, morteros fabricados con adición y sustitución de distintas breas para evaluar la posibilidad de proponer una nueva vía de valorización de estos materiales mediante su incorporación a materiales de construcción más sostenibles con el medio ambiente.

\section{PARTE EXPERIMENTAL}

\subsection{Materiales utilizados y preparación de morteros}

Para la realización de este estudio se han utilizado los siguientes materiales: cemento Portland CEM I 52.5R (CP) y arena silícea normalizada cumpliendo la norma europea UNE-EN 196-1 (9). La Tabla 1 muestra el análisis químico del cemento Portland utilizado.
Natural tar is a high molecular weight by-product of oil and coal pitch distillation. Oil and coal tar comprise a complex mix of primarily aromatic and heterocyclic hydrocarbons (4). Their high aromatic content explains their speedy reaction in coke formation. Tar contains four groups of chemicals: saturated, naphthalene, polar aromatic and asphaltene compounds (5).

Unlike carbon fibres, which have been extensively studied for their potential to strengthen concrete (6-7), these materials have not been used to date as additions to reinforce Portland cement mortars. The results of a comparative study between mortars made with carbon fibre and others made with low softening point petroleum tar were reported in a previous paper (8). The promising results obtained led to a decision to pursue the issue by characterizing the mechanical behaviour of mortars made with different types of natural tar. The subject of the present study, then, is this by-product of the coal and oil industries.

Despite its - a priori- poorer mechanical properties, tar was felt to be a worthwhile object of analysis as a possible reinforcement for mortar, given its low cost, specifically in comparison to carbon fibre.

The purpose of this study was to characterize the mechanical strength of mortars made with different types of tar to evaluate the feasibility of re-using these compounds in the manufacture of more environmentally-friendly construction materials.

\section{EXPERIMENTAL}

\subsection{Materials used and preparation of mortars}

The following materials were used for this study: CEM I 52.5R Portland cement and standardized siliceous sand as per Spanish and European standard UNE-EN 196-1 [9]. The chemical analysis of the Portland cement used is given in Table 1.

Tabla 1 / Table 1

Análisis químico de cemento Portland

Chemical analysis of Portland cement

\begin{tabular}{|c|c|c|c|c|c|c|c|c|}
\hline $\mathbf{\%}$ & $\mathbf{C a O}$ & $\mathbf{S i O}_{\mathbf{2}}$ & $\mathbf{A l}_{\mathbf{2}} \mathbf{O}_{\mathbf{3}}$ & $\mathbf{M g O}$ & $\mathbf{F e}_{\mathbf{2}} \mathbf{O}_{\mathbf{3}}$ & $\mathbf{S O}_{\mathbf{3}}-$ & $\mathbf{K}_{\mathbf{2}} \mathbf{O}$ & $\mathbf{N a}_{\mathbf{2}} \mathbf{O}$ \\
\hline Cemento / Cement & 61.8 & 19.2 & 4.99 & 2.6 & 2.7 & 3.6 & 0.93 & - \\
\hline
\end{tabular}


Se han utilizado los siguientes materiales carbonosos:

Breas de alquitrán de carbón de hulla $A$ (BACA) y $B$ (BACB), suministradas por el Departamento de Química Inorgánica de la Universidad de Alicante. Ambas son breas aromáticas de bajo punto de reblandecimiento ( $\mathrm{Tr}=$ 383 oK y 346 K, respectivamente).

Brea de petróleo precursora de fibra de carbón (BPP) suministrada por el Departamento de Química Inorgánica de la Universidad de Alicante. Es una brea de bajo punto de reblandecimiento $\left(\mathrm{Tr}=410^{\circ} \mathrm{K}\right)$.

Brea de petróleo precursora de fibras de brea tratadas (BPT) suministrada por el Departamento de Química Inorgánica de la Universidad de Alicante. Es una brea de alto punto de reblandecimiento $\left(\mathrm{Tr}=488^{\circ} \mathrm{K}\right)$.

Estas breas de petróleo presentan un carácter menos aromático que las de carbón.

El punto de reblandecimiento es importante por si la reacción exotérmica de hidratación de cemento pudiera modificar las características del material carbonoso y, por tanto, su interacción con la pasta cementicia.

En cualquier caso, las temperaturas de reblandecimiento de las breas son superiores a las temperaturas de fraguado de los morteros, lo que hace que este parámetro deba ser conocido aunque no afecte significativamente.

La Figura 1 muestra las imágenes de microscopía electrónica de los materiales carbonosos utilizados. Para todas ellas se observa la forma irregular de las partículas. En el caso de las breas de alquitrán de carbón es destacable la rugosidad de su superficie.

La Tabla 2 muestra la composición química elemental de las distintas breas estudiadas. El contenido en carbono de todas ellas está comprendido entre el 91 y el 94\%, contenidos habituales en estos materiales carbonosos. El contenido en $\mathrm{H}$ es similar en ambos tipos de brea, siendo más alto en el caso de las breas de petróleo en concordancia con su menor carácter aromático. El contenido en $\mathrm{N}$ es despreciable en las breas de petróleo. El azufre es despreciable para la BPT.
The following carbonaceous materials were used:

$A-(B A C A)$ and $B-(B A C B)$ type hard coal tar, supplied by the of the University of Alicante's Department of Inorganic Chemistry. Both are aromatic tars with a low softening point ( $T s=383$ and $346^{\circ} \mathrm{K}$, respectively).

Petroleum tar, a coal fibre precursor (BPT), supplied by the University of Alicante's Department of Inorganic Chemistry. This tar also has a low softening point (Ts $\left.=410^{\circ} \mathrm{K}\right)$.

Petroleum tar, a tar fibre precursor (BPT), supplied by the University of Alicante's Department of Inorganic Chemistry. This tar has a high softening point (Ts = $\left.488^{\circ} \mathrm{K}\right)$.

These petroleum tars were less aromatic than the coal materials.

The softening point is important to ensure that the exothermal cement hydration reaction does not modify the tar characteristics and therefore its interaction with the cement paste.

In any event, tar softening point temperatures are higher than the mortar setting temperatures; consequently, while the value of the former should be known, their actual impact is of minor significance.

Figure 1 shows electron microscope images of the carbonaceous materials used. The particles were observed to be irregularly shaped in all four and in the coal tars to have a rough surface.

The elementary composition of the various tars studied is given in Table 2. The carbon content in all cases ranged from 91 to 94\%, values typically found in such carbonaceous materials. While similar in the coal and petroleum tars, the $H$ content was higher in the latter, in keeping with its less aromatic nature. The nitrogen content was negligible in both petroleum tars, as was the sulphur content in BPT.

Tabla 2 / Table 2

Composición química elemental de los distintos materiales carbonosos Chemical composition of the carbonaceous materials

\begin{tabular}{|l|c|c|c|c|}
\hline \multirow{2}{*}{ Muestra / Sample } & \multicolumn{4}{|c|}{ Análisis elemental (\% en peso) / Elementary analysis (in \% by weight) } \\
\cline { 2 - 5 } & C & H & N & (S+0) dif $^{\text {( }}$ \\
\hline BPP & 92.29 & 5.53 & 0.02 & 2.16 \\
\hline BPT & 94.06 & 5.91 & 0.03 & - \\
\hline BACA & 92.13 & 4.46 & 0.77 & 2.64 \\
\hline BACB & 91.85 & 4.79 & 0.79 & 2.65 \\
\hline
\end{tabular}




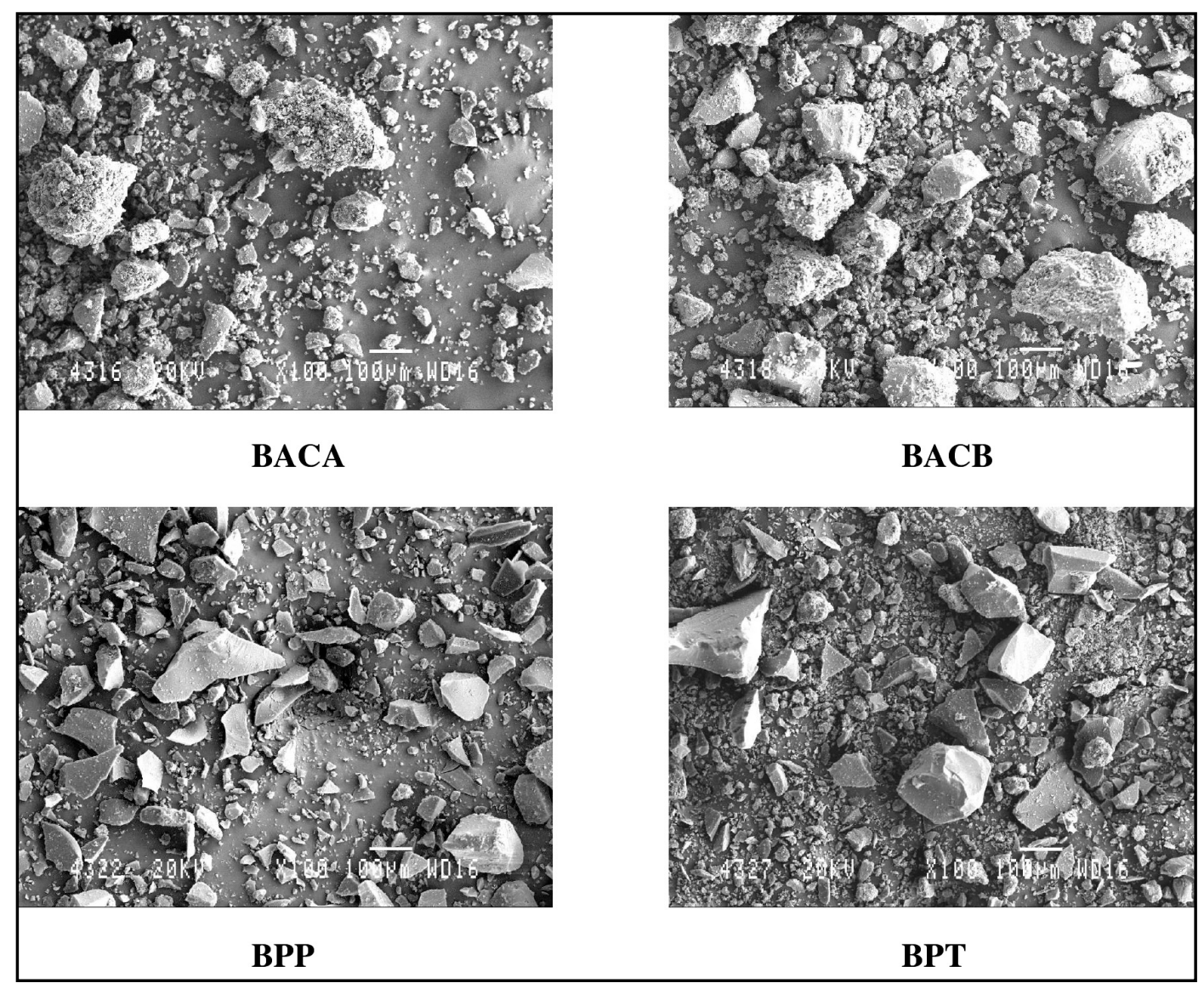

Figura 1. Imágenes de microscopía electrónica de los materiales carbonosos.

Figure 1. Electron microscope images of the carbonaceous materials.

La Figura 2 muestra la distribución granulométrica obtenida mediante difracción de luz láser de los diferentes materiales empleados para la fabricación del mortero, habiendo utilizado para la arena normalizada exclusivamente la fracción fina que pasa por el tamiz 0,16 $\mu \mathrm{m}$. El valor de la mediana $\left(D_{50}\right)$ de la distribución de partículas en volumen que nos indica el valor, en $\mu \mathrm{m}$, por debajo del cual se encuentra el $50 \%$ del volumen de las partículas es el siguiente para cada uno de los materiales estudiados: cemento: 15,9 $\mu \mathrm{m}, \mathrm{BPT}$ : $35,1 \mu \mathrm{m}$; BACB: 42,6 $\mu \mathrm{m}$; BACA: 49,1 $\mu \mathrm{m}$; BPP: 48,6 $\mu \mathrm{m}$; y arena: 80,5 $\mu \mathrm{m}$. Se puede observar que el tamaño de partícula es muy similar entre ellas y comprendido entre el del cemento y el de la arena, lo que podría contribuir a un posible efecto fíller por parte de estos materiales.

Todos los morteros estudiados se han fabricado y curado bajo agua a $20{ }^{\circ} \mathrm{C}$, siendo los tiempos de curado: 2, 28 y 120 días. La relación en peso agua/conglomerante ha sido de 0,5. La incorporación de la brea al mortero se ha realizado utilizando distintos porcentajes de adición o sustitución sobre el peso de conglomerante: 0 (mortero patrón), 0,5, 1 y 3\%. En los morteros con adición de brea se ha utilizado una relación arena/conglomerante $=3$. Para los morteros con sustitución parcial de cemento por brea, la relación arena/(conglomerante: $\mathrm{CP}+$ brea $)=3$.
Figure 2 shows the particle size distribution obtained with laser techniques for the materials used to make the mortar; only the fraction of the standardized sand that passing the $0.16-\mu \mathrm{m}$ sieve was used. The median value $\left(D_{50}\right)$ by volume of the particle size for the materials studied, i.e., the size in $\mu \mathrm{m}$ of the sieve passed by $50 \%$ of the particles, was as follows: cement: $15.9 \mu \mathrm{m}$, BPT: $35.1 \mu \mathrm{m}$, BACB: $42.6 \mu \mathrm{m}$, BACA: $49.1 \mu \mathrm{m}, B P P: 48.6 \mu \mathrm{m}$, sand: $80.5 \mu \mathrm{m}$. With a particle size both similar for the four types and within the range bounded by the cement and sand particle sizes, the tars might be expected to act as fillers.

All the mortars studied were manufactured and cured under water at $20{ }^{\circ} \mathrm{C}$ for 2, 28 or 120 days. The water/binder ratio was 0.5 . The percentages of the addition used (by binder weight) were: 0 (control mortar), $0.5,1$ and $3 \%$. In the mortars with tar additions the sand/binder ratio used was 3. In the mortars in which the tar partially replaced the cement, the sand/binder ratio was binder : $P C+\operatorname{tar}=3$. 


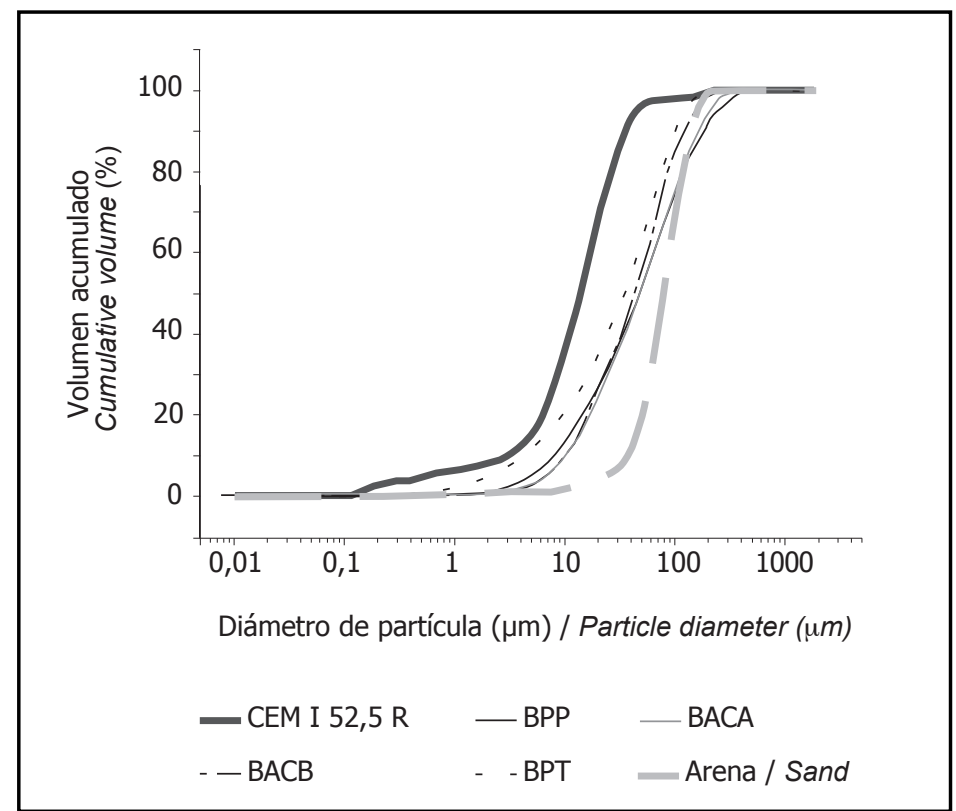

Figura 2. Granulometrías de los distintos materiales carbonosos utilizados en este trabajo mediante difracción láser.

Figure 2. Particle size distribution of the carbonaceous materials used in this study, determined by laser diffraction.

\subsection{Ensayos}

Se ha determinado el principio y fin de fraguado según lo establecido en la norma EN 196-3 (10) en pastas fabricadas con diferentes porcentajes de sustitución de cemento por brea. Por otro lado, se ha determinado la consistencia del mortero según la norma UNE 1015-3 (11).

A los distintos morteros fabricados se les ha determinado las resistencias mecánicas a flexotracción y compresión, así como la porosidad abierta. Para ello se han fabricado probetas prismáticas de $4 \times 4 \times 16 \mathrm{~cm}$ mediante compactación mecánica en dos capas. Los ensayos mecánicos se han realizado en condiciones de laboratorio según lo establecido en la norma EN 196-1 (9).

\section{RESULTADOS Y DISCUSIÓN}

La Figura 3 muestra los datos de resistencia a compresión a 120 días para morteros fabricados con diferentes porcentajes de adición sobre el peso de cemento de las distintas breas estudiadas, expresados como Rci/Rco, donde Rci es el valor de la resistencia a compresión para un mortero dado y Rco es el valor para el mortero patrón. En ella se puede observar que los mejores resultados en todos los casos se obtienen para porcentajes de adición de $0,5 \%$ y que conforme aumenta el porcentaje de adición de brea, disminuye la resistencia mecánica del mortero. A este comportamiento podría contribuir la mayor demanda de agua provocada por la adición de brea sobre el peso de cemento, manteniendo la relación agua/conglomerante

\subsection{Tests}

The initial and final setting times were found for the pastes made with different percentages of tar as stipulated in European standard EN 196-3 (10). Mortar consistency was determined, in turn, to Spanish standard UNE 1015-3 (11).

Mortar bending and compressive strengths as well as open porosity were found with prismatic specimens measuring $4 \times 4 \times 16 \mathrm{~cm}$, cast and consolidated in two lifts. The mechanical tests were conducted under laboratory conditions as specified in European standard EN 196-1 (9).

\section{RESULTS AND DISCUSSION}

Figure 3 shows the 120-day compressive strength data for mortars made with different percentages of tar additions, expressed as a fraction of the compressive strength value found for the control (Rci/Rco). The best results were obtained in all cases for addition the mortars containing $0.5 \%$ additions, with mechanical strength declining as the percentage of tar rose. This behaviour may be partly explained by the higher water demand, at a constant water/binder ratio, generated by the tar, whose particles were smaller in size and had a rougher surface than the sand particles. Generally speaking, compressive strength was observed to decline more with coal tars (BACA and BACB) than 
constante, dado su tamaño de partícula inferior al de la arena y a la rugosidad superficial de las partículas de brea. También se observa que, en general, las breas de alquitrán de carbón (BACA y BACB) proporcionan una mayor pérdida de resistencia a compresión al mortero, en comparación con lo observado para los morteros con brea de petróleo (BPP y BPT). Sin embargo, hay que destacar que la magnitud de pérdida de resistencia mecánica a compresión, con respecto al patrón de los morteros fabricados con adición de estas breas, es inferior al 5\%, lo que implica que en función de las futuras aplicaciones del mortero se podrían asumir disminuciones mayores de la misma, siendo posible formular morteros con mayores porcentajes de adición de brea. Finalmente se puede considerar que la BPP es la brea que mejor comportamiento ofrece para todos los porcentajes de adición estudiados.

La Figura 4 muestra los datos de resistencia a compresión a 120 días para morteros fabricados con diferentes porcentajes de sustitución sobre el peso de cemento de las distintas breas estudiadas. En ella se puede observar que conforme aumenta el porcentaje de sustitución de brea, disminuye la resistencia mecánica del mortero, aunque no de forma tan marcada como en el caso de adición. De hecho las diferencias entre 0,5 y $1 \%$ no son significativas. En concreto para el 1\% de sustitución, estas breas mejoran, en general, el comportamiento del patrón, lo que valoriza su uso como carga inerte en morteros y hormigones. Estos resultados son coherentes con el estudio previo en el cual se ha utilizado, entre otros materiales carbonosos, una brea de petróleo de alto punto de reblandecimiento (8).

Las breas de petróleo ofrecen las mejores prestaciones mecánicas para bajos porcentajes de sustitución. Sin embargo, para mayores porcentajes de sustitución, 3\%, es la BACA la que mejor comportamiento presenta. En general, de nuevo la pérdida de resistencia mecánica que experimentan los morteros con sustitución de cemento por brea frente al patrón es, como máximo, del $5 \%$ para todos los casos, excepto para el BPP al $3 \%$, que asciende al $10 \%$. Estos resultados son coherentes con la naturaleza granulométrica de estos materiales.

Dado que los morteros fabricados con sustitución parcial de cemento por brea presentan mejor comportamiento mecánico que los fabricados con adición de brea, se presentan a continuación los resultados de la evolución de resistencias mecánicas de morteros fabricados con sustitución de breas. Se ha elegido una de alquitrán, BACA, y otra de petróleo, BPP, que son las que en general han ofrecido mejor comportamiento. De esta manera se trata de profundizar en el comportamiento de estos morteros y poder constatar si son materiales adecuados para ser valorizados mediante su incorporación a los mismos que, a su vez, al poder ser fabricados con menos cemento, serán más sostenibles. with the petroleum products (BPP and BPT). Nonetheless, these mortars showed compressive strength values less than $5 \%$ lower than observed in the control. Depending on the future use of the mortar, therefore, greater declines could be allowed, and consequently higher percentages of tar additions could be used. Finally, BPP was the tar that exhibited the best overall behaviour for all the percentages of addition studied.

Figure 4 shows the 120-day compressive strength for mortars in which different percentages of cement were replaced by the various tars studied. As the percentage of tar rose, the mechanical strength of the mortar dropped, but not as steeply as in the case of the additions. Indeed, the differences between 0.5 and $1 \%$ were insignificant. More specifically, the mortars with $1 \%$ replacements performed better than the control, ratifying the suitability of tar as an inert filler in mortars and concretes. These results are consistent with a prior study comparing the performance of a number of carbonaceous materials, a petroleum tar with a high softening point among them [8].

At low substitution percentages, the mortars containing petroleum tars were found to be strongest. At 3\%, however, the best performance was recorded for BACA. The loss of mechanical strength in the mortars in which tar partially substituted the cement was under $5 \%$ in all cases except for 3\% BPP, where strength declined by $10 \%$. These results are consistent with the particle size of the various materials.

Since the mortars in which the cement was partially replaced by tar performed better than the materials containing tar additions, the following discussion of the results of the variation in mechanical strength focuses on the former, and more specifically on the coal tar, $B A C A$, and the petroleum by-product, BPP, exhibiting the best overall performance. The intention was to study the behaviour of such mortars in greater depth and determine whether these tars are suitable for inclusion in mortars to produce a more sustainable material whose manufacture would require less cement. 


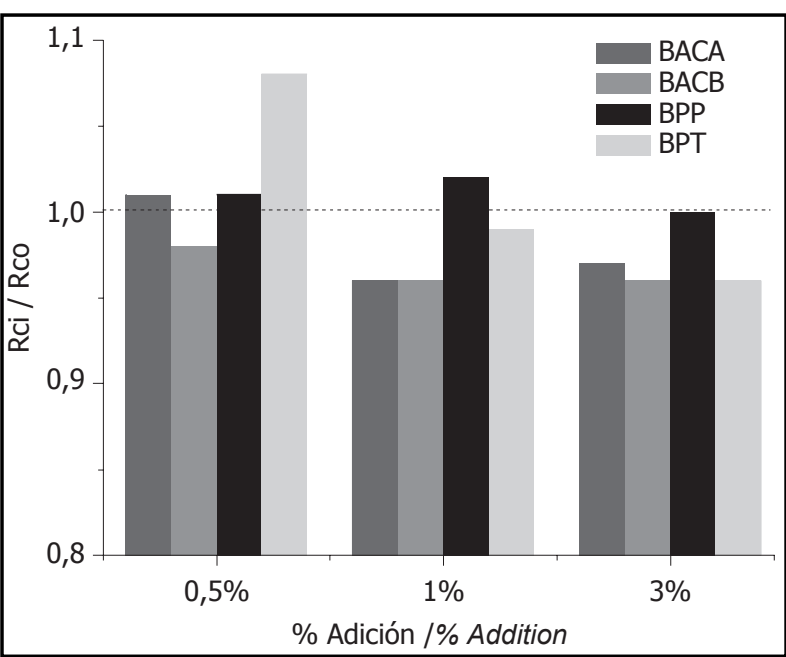

Figura 3. Resistencia a compresión a 120 días para morteros fabricados con diferentes porcentajes de adición sobre el peso de cemento de las distintas breas estudiadas. (Rci: valor de la resistencia a compresión para un mortero dado, Rco: valor para el mortero patrón.)

Figure 3. 120-day compressive strength for mortars made with different percentages (by weight of cement) of the four tar additions studied. (Rci: compressive strength for a given mortar; Rco: control strength.)

En la Tabla 3 se muestra el tiempo de trabajabilidad de las pastas y la consistencia de los morteros, expresada como el diámetro de escurrimiento medio para conglomerados fabricados con diferentes porcentajes de sustitución de cemento por BACA. En ella se puede observar que conforme aumenta el porcentaje de sustitución, se produce, por una parte, un adelanto tanto en el inicio como en el final del fraguado, acompañado de un ligero aumento del tiempo de trabajabilidad de la pasta. Y por otra, se observa una leve disminución de la trabajabilidad del mortero debido, probablemente, a la mayor demanda de agua que genera la brea dada su textura rugosa que favorece la absorción de agua por parte de la misma.

En la Figura 5 se muestra la evolución de la resistencia a flexión de morteros fabricados con $0,0,5,1$ y $3 \%$ en peso de sustitución de cemento por BACA. En las gráficas aparece en línea discontinua el intervalo de confianza del $95 \%$. El intervalo de confianza implica que en él se encuentra el verdadero valor del experimento, nunca conocido exactamente, con un grado prefijado de seguridad.

En primer lugar, se observa un progresivo aumento de la Rf con respecto al tiempo, siendo éste más marcado entre 2 y 28 días que entre 28 y 120 días, reflejando un comportamiento habitual en este tipo de morteros. Es destacable que la sustitución del $0,5 \%$ de cemento por BACA mejora el comportamiento mecánico a flexión del mortero patrón. Por otra parte, la sustitución de un $1 \%$ prácticamente mantiene el mismo comportamiento que el mortero patrón. Por el contrario, mayores porcentajes de sustitución, $3 \%$, muestran

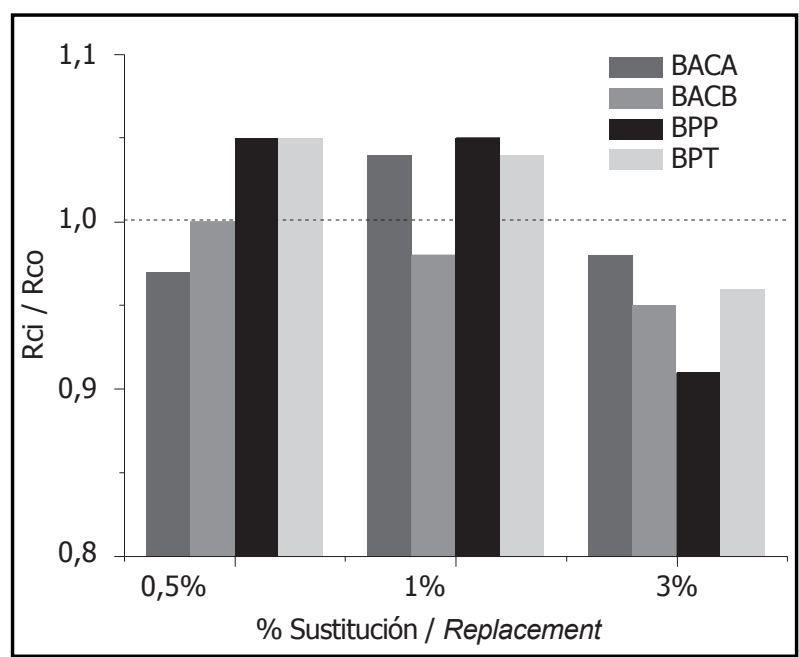

Figura 4. Resistencia a compresión a 120 días para morteros fabricados con diferentes porcentajes de sustitución sobre el peso de cemento de las distintas breas estudiadas. (Rci: valor de la resistencia a compresión para un mortero dado, Rco: valor para el mortero patrón.)

Figure 4. 120-day compressive strength for mortars containing different percentages of tar (by weight) as a cement replacement. (Rci: compressive strength for a given mortar; Rco: control strength.)

Table 3 shows the workability times for the pastes and the mortar consistency expressed as the mean slump diameter for binders made with different percentages of $B A C A$. The data show, on the one hand, that both the initial and final setting times were shortened as the percentage of tar increased, while the paste workability time was lengthened slightly. In addition, a minor decline was observed in mortar workability, due in all likelihood to the greater water demand generated by the rough texture of the tar.

Figure 5 shows the variation in bending strength in mortars in which BACA replaced $0,0.5,1$ and $3 \%$ of the cement (by weight). The dotted lines denote the 95\% confidence intervals. The confidence interval implies that the actual experimental value, which is never known exactly, lies within that interval with a pre-established probability.

Typically for such mortars, a steady increase in Rf was observed with time, with a steeper rise between 2 and 28 than between 28 and 120 days. When $0.5 \%$ of cement was replaced with BACA, flexural strength was higher than in the control mortar. When $1 \%$ was replaced, the performance was practically the same as in the control. At higher replacement percentages (3\%), however, bending strength declined. In any event, for a 95\% confidence level, replacing cement with tar caused 
Tabla 3 / Table 3

Propiedades físicas de conglomerados fabricados con 0,1 y $3 \%$ de sustitución de cemento por BACA Physical properties of binders made with 0, 1 and 3\% BACA

\begin{tabular}{|c|c|c|c|}
\hline \multirow{2}{*}{$\begin{array}{c}\text { \% sustitución BACA / } \\
\text { BACA }\end{array}$} & \multicolumn{2}{|c|}{ Tiempo de fraguado (min) / Setting time (min) } & \multirow{2}{*}{$\begin{array}{c}\text { Escurrimiento medio (mm) } \\
\text { Mean s/ump (mm) }\end{array}$} \\
\cline { 2 - 3 } & Inicio / Initial & Final / Final & 175 \\
\hline 0 & 210 & 330 & 170 \\
\hline 1 & 195 & 320 & 160 \\
\hline 3 & 180 & 310 & \\
\hline
\end{tabular}

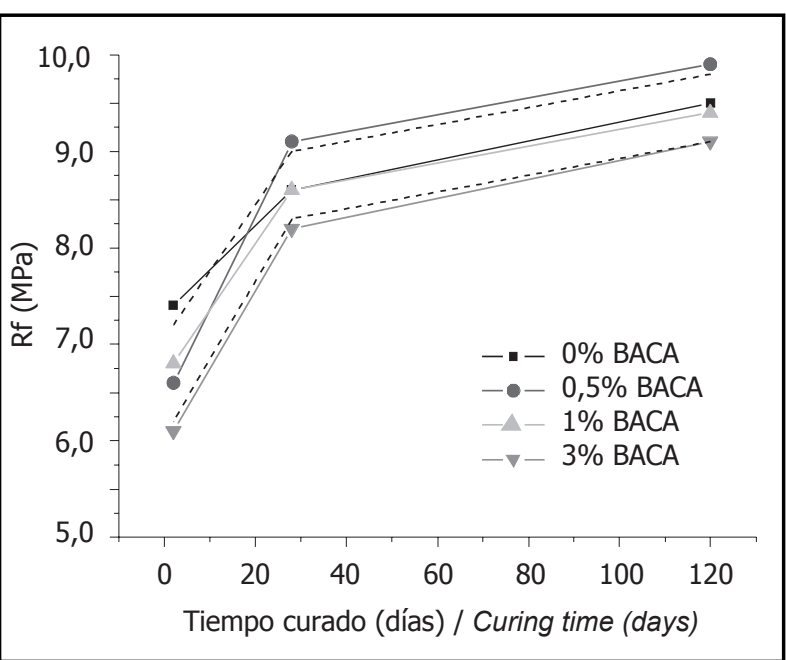

Figura 5. Evolución de la resistencia a flexión (Rf) de morteros fabricados con diferentes porcentajes de sustitución de cemento por brea de alquitrán de carbón. (Las líneas discontinuas representan el intervalo de confianza del $95 \%$.)

Figure 5. Flexural strength (Rf) of mortars containing different percentages of coal tar as a cement replacement vs curing time. (The dotted lines denote the 95\% confidence intervals.)

unas peores características resistentes a flexión. Ahora bien, se debe establecer que para un nivel de confianza del 95\%, las sustituciones realizadas no modifican significativamente su resistencia a flexión con respecto al patrón, excepto la del $3 \%$ que queda muy en el límite.

En la Figura 6 se muestra la evolución de la resistencia a compresión de morteros fabricados con $0,0,5,1$ y $3 \%$ de sustitución de cemento por BACA.

Análogamente a lo observado en la Rf, la evolución en la resistencia a compresión presenta un aumento progresivo con el tiempo de curado. Si bien a 28 días, el porcentaje de sustitución de 0,5 y $1 \%$ mejoran al patrón, a mayores tiempos de curado, la sustitución del $1 \%$ es la que mejor comportamiento presenta. De nuevo el estudio estadístico demuestra que para un nivel de confianza del 95\%, los resultados obtenidos en los morteros con distintos porcentajes de sustitución no son significativamente distintos a los del patrón. Estos resultados de Rc para los morteros fabricados con sustitución de cemento por BACA son totalmente coherentes con los valores medidos de porosidad a 120 días que se muestran en la Tabla 4.

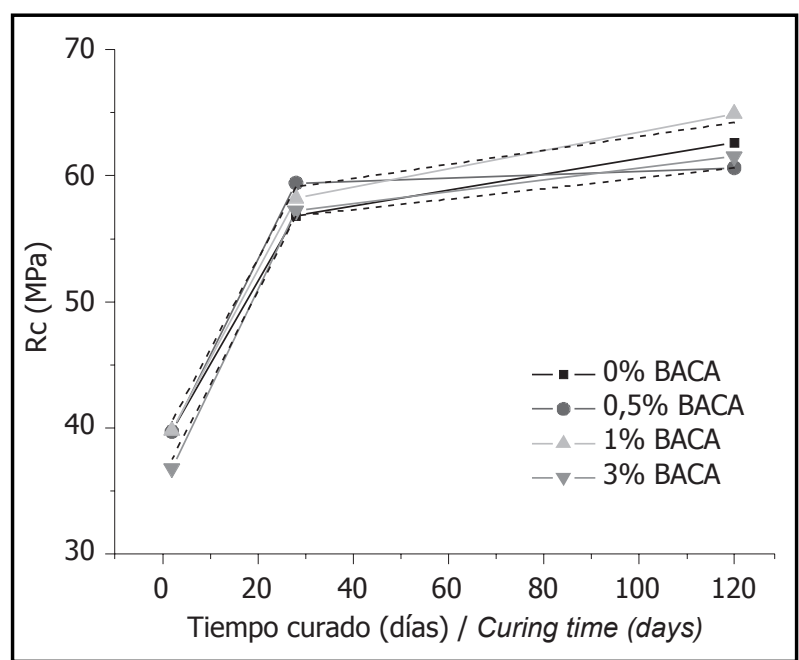

Figura 6. Evolución de la resistencia a compresión (Rc) de morteros fabricados con diferentes porcentajes de sustitución de cemento por brea de alquitrán de carbón (BACA). (Las líneas discontinuas representan el intervalo de confianza del 95\%.)

Figure 6. Compressive strength $(R C)$ of mortars containing

different percentages of coal tar (BACA) as a cement replacement vs curing time. (The dotted lines denote the 95\% confidence intervals.)

no significant change in bending strength, except in the case of the highest replacement percentage, which even then was only barely significant.

Figure 6 shows the variation in compressive strength in mortars in which BACA replaced 0, 0.5, 1 and 3\% of the cement (by weight).

As in the Rf findings, compressive strength grew with curing time. While the 28-day strength for mortars with both 0.5 and $1 \%$ replacements was greater than for the control, at longer curing times the best performance was found for the $1 \%$ mortar. Here also the statistical study showed that the results for the mortars with different percentages of tar were not significantly different from the values found for the control at the $95 \%$ confidence level. The $R c$ results for mortars in which the cement was replaced by BACA were wholly consistent with the 120-day porosity values given in Table 4. 
Por tanto, se puede concluir que la sustitución de cemento por BACA en porcentaje de hasta el $3 \%$ en peso permite obtener morteros que cumplen con las prescripciones mecánicas exigidas por la norma UNE-EN 197-1 (12). Queda demostrado, de esta manera, esta vía alternativa como aplicación novedosa de estos materiales. $A$ la vista de estos resultados se deberían hacer estudios posteriores que permitieran establecer el máximo porcentaje de sustitución para obtener morteros que, aunque con menor resistencia mecánica que el patrón, sean aptos para distintas aplicaciones en construcción, permitiendo así utilizar la máxima cantidad de breas.

En la Figura 7 se muestra la evolución de la resistencia a flexión de morteros fabricados con $0,0,5,1$ y $3 \%$ de sustitución de cemento por BPP.

De nuevo vuelve a observarse un aumento progresivo de las resistencias a flexión con la edad de curado. Por otra parte, para la sustitución del $1 \%$ se observa un aumento de la Rf a 120 días que puede considerarse significativo de la misma. Por el contrario, para un 3\% se observa, durante todo el tiempo de curado, una disminución, también significativa, de dicha resistencia.
It may consequently be concluded that replacing cement with up to $3 \%$ BACA by weight yields mortars that meet the mechanical requirements laid down in Spanish and European standard UNE EN 197-1 [12]. The foregoing confirms the viability of this alternative route for reusing such materials. In light of these results and to maximize the amount of tar recycled, subsequent studies should be conducted to determine the ceiling percentage for making replacement mortars which, despite their lower strength, may be suitable for certain uses in construction.

Figure 7 shows the variation in bending strength in mortars in which BPP replaced 0, 0.5, 1 and $3 \%$ of the cement (by weight).

In this case, flexural strength was again observed to rise gradually with curing age. Moreover, the 120-day Rf for the $1 \%$ mortar showed what may be regarded to be a significant increase. On the contrary, a likewise significant decline was observed for the 3\% material at all three ages.

Tabla 4 / Table 4

Datos de porosidad a 120 días de morteros con sustitución BACA y BPP 120-day porosity in mortars containing BACA and BPP

\begin{tabular}{|l|c|c|c|c|c|c|c|c|}
\hline \multicolumn{1}{|c|}{ BREA / TAR } & \multicolumn{4}{c|}{ BACA } & \multicolumn{4}{c|}{ BPP } \\
\hline$\%$ sustitución / \% Replacement & $0 \%$ & $0.5 \%$ & $1 \%$ & $3 \%$ & $0 \%$ & $0.5 \%$ & $1 \%$ & $3 \%$ \\
\hline Porosidad / Porosity & $16.8 \%$ & $17.0 \%$ & $16.6 \%$ & $16.8 \%$ & $16.8 \%$ & $17.1 \%$ & $16.1 \%$ & $16.2 \%$ \\
\hline
\end{tabular}

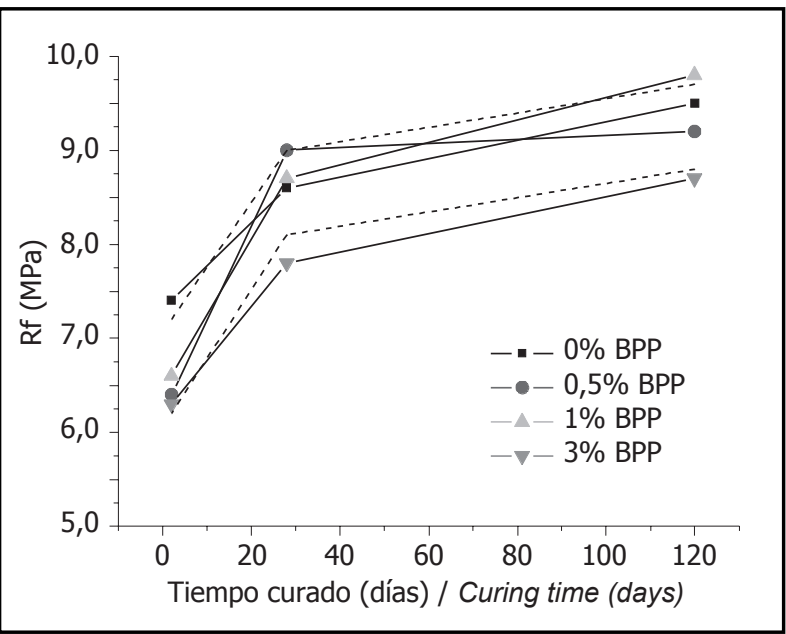

Figura 7. Evolución de la resistencia a flexión (Rf) de morteros fabricados con diferentes porcentajes de sustitución de cemento por brea de petróleo (BPP). (Las líneas discontinuas representan el intervalo de confianza del $95 \%$.)

Figure 7. Flexural strength (Rf) of mortars containing different percentages of petroleum tar (BPP) as a cement replacement vs curing time. (The dotted lines denote the $95 \%$ confidence intervals.)

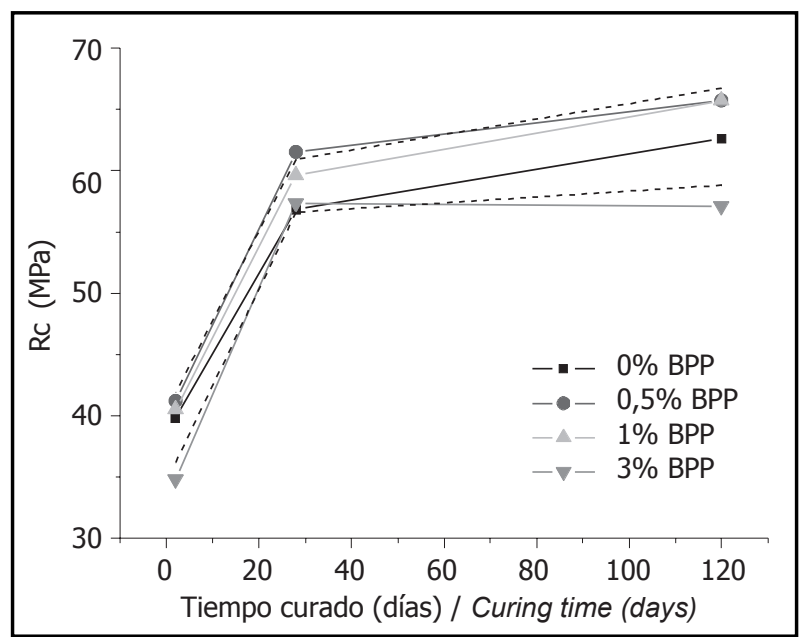

Figura 8. Evolución de la resistencia a compresión (Rc) de morteros fabricados con diferentes porcentajes de sustitución de cemento por brea de petróleo (BPP). (Las líneas discontinuas representan el intervalo de confianza del $95 \%$.)

Figure 8. Compressive strength (Rc) of mortars containing different percentages of petroleum tar (BPP) as a cement replacement. vs curing time (The dotted lines denote the 95\% confidence intervals.) 
En la Figura 8 se muestra la evolución de la resistencia a compresión de morteros fabricados con $0,0,5,1$ y $3 \%$ de sustitución de cemento por BPP.

Además del esperado aumento de las resistencias con el tiempo, se observa que para porcentajes de sustitución de 0,5 y $1 \%$, se obtienen valores mayores que el patrón. Si bien estos valores no pueden considerarse significativamente distintos a los del patrón. Por el contrario, para el 3\% de sustitución se observan valores menores y, además, significativamente distintos para un $95 \%$ de probabilidad. Los valores de porosidad obtenidos por estos morteros a 120 días, Tabla 4, no son coherentes con el comportamiento mecánico observado salvo en el caso del 1\%, que presentan valores más bajos de la porosidad, en relación con el patrón.

Por tanto, como conclusión, se puede indicar que para la BPP, porcentajes de sustitución hasta del $1 \%$ no modifican significativamente las características mecánicas con respecto al mortero patrón. Porcentajes superiores, 3\%, muestran una pérdida significativa de características resistentes.

\section{CONCLUSIÓN}

Este estudio demuestra que la incorporación de breas a los morteros de cemento proporciona conglomerados que cumplen las prescripciones mecánicas exigidas por la norma, lo que abre una nueva aplicación de estos materiales carbonosos y permite reducir el consumo de cemento, siendo ecológicamente más respetuosos con el medio ambiente.
Figure 8 shows the variation in compressive strength in mortars in which BPP replaced 0, 0.5, 1 and $3 \%$ of the cement (by weight).

In addition to the anticipated increase in strength with time, higher values were obtained for the 0.5 and $1 \%$ mortars than for the control, although these differences cannot be considered to be significant. By contrast, significantly smaller values were found for the 3\% mortar at a 95\% confidence interval. The 120-day porosity values obtained for these mortars (Table 4), are not consistent with the mechanical behaviour observed, except in the case of the $1 \%$ replacement, which had lower porosity values than the control.

By way of conclusion, in BPP mortars, tar percentages of up to $1 \%$ did not significantly modify the mechanical characteristics of the material. A significant decline in strength was recorded for higher percentages (3\%).

\section{CONCLUSION}

This study shows that including tar in cement mortars yields binders that meet the mechanical requirements laid down in the applicable standards. The resulting new use of these carbonaceous materials entails a reduction in cement consumption, making the final product doubly beneficial for the environment.

\section{BIBLIOGRAFÍA / BIBLIOGRAPHY}

(1) Rodríguez-Reinoso, F. y Marsh, H. (eds.): Sciences of Carbon Materials, Publicaciones de la Universidad de Alicante, 2000.

(2) Donnet, J. B., Rebouillat, T. S., Wang, T. K. y Peng, J. C. M. (eds): Carbon Fibers, Marcel Dekker Inc., Nueva York, 1998.

(3) Alcañiz Monge, J., Cazorla Amorós, D., Linares Solano, A.: Fibras de Carbón: preparación y aplicaciones, Publicaciones de la Universidad de Alicante, 1998.

(4) Zander, M.: Fuel, vol. 66 (1987), 1536.

(5) Rand, B., Hasty, A. J. y West, S.: Introduction to carbon science. (Ed. H. Marsh). Butterworths, 1989.

(6) Garcés, P., Fraile, J., Vilaplana-Ortego, E., Cazorla-Amorós, D., G.a Alcocel, E. y G. a Andión, L.: "Effect of Carbon fibers on the mechanical properties and corrosion levels of Portland cement mortars", Cem. Concr. Res., vol. 35 (2005), pp. 324-331.

(7) Chung, D. D. L.: "Cement reinforced with short fibers: A Multifunctional material", Composites part B, vol. 31 (2000), pp. 511-526.

(8) Alcaide, J. S., Vilaplana, E., Andión L. G., G.a Alcocel, E., Linares, A. y Garcés P.: "Influence of the Addition of Petroleum Pitch and Other Carbon Materials in the Mechanical Properties of Portland Cement Mortars", ACI Materials Journal. (Submitted)

(9) UNE-EN 196-1: "Métodos de ensayo de cementos. Parte 1: Determinación de resistencias mecánicas".

(10) UNE-EN 196-3: "Método de ensayo de cementos. Parte 3. Determinación del tiempo de fraguado y de la estabilidad de volumen".

(11) UNE-EN 1015-3: "Métodos de ensayo de morteros de albañilería. Parte 3: Determinación de la consistencia del mortero fresco (por la mesa de sacudidas)".

(12) UNE-EN 197-1: "Cemento. Parte 1: Composición, especificaciones y criterios de conformidad de cementos comunes".

Los autores agradecen a la Generalitat Valenciana la subvención recibida para la realización de este trabajo (Ref. CTIDIB/2002/164). 